\title{
KEIKATAN KERJA KARYAWAN DITINJAU DARI BUDAYA KESELAMATAN DAN KESEHATAN KERJA
}

Lily Marian dan Haryanto F. Rosyid

\begin{abstract}
Abstrak
Penelitian ini bertujuan untuk mengetahui hubungan antara budaya keselamatan dan kesehatan kerja dengan keikatan kerja karyawan. Rumusan hipotesis yang diuji dalam penelitian ini ialah: ada hubungan positif antara budaya keselamatan dan kesehatan kerja dengan keikatan kerja karyawan. Subyek penelitian terdiri atas 94 orang karyawan yang telah memiliki masa kerja minimal 1 tahun, dan pendidikan minimal SLTA atau sederajat pada sebuah industri tekstil di kawasan Surakarta. Program korelasi productmoment dari Pearson digunakan untuk menguji kebenaran rumusan hipotesis diatas. Analisis data yang dilakukan menghasilkan koefisien korelasi antara variabel budaya keselamatan dan kesehatan kerja dengan variabel keikatan kerja sebesar $(r)=0,771 ; p<0,01$.

Hasil ini menunjukkan bahwa hipotesis yang diajukan dapat diterima, berarti ada hubungan positif antara variabel budaya keselamatan dan kesehatan kerja dengan keikatan kerja karyawan. Hasil lain yang perlu diperhatikan ialah Budaya keselamatan dan kesehatan kerja menyumbang sebesar $59,5 \%$ terhadap pembentukan keikatan kerja (koefisien determinan $r^{2}=0,595$ )., sedangkan sisanya sebesar $40,5 \%$ disumbang oleh faktor lain yang tidak diteliti dalam penelitian ini.
\end{abstract}

Kata Kunci : budaya keselamatan dan kesehatan kerja (K3), keikatan kerja.

\section{PENGANTAR}

Indonesia memasuki era globalisasi di abad milenium baru. Era tersebut di warnai oleh persaingan bisnis yang ketat menyongsong AFTA tahun 2003, sehingga segala sesuatunya perlu dipesiapkan agar tetap dapat tumbuh, survive, dan berkembang. Hal ini berarti permasalahan yang ada semakin bertambah kompleks berkaitan dengan penyediaan sumber daya manusia yang bermutu, karena betapa maju dan moderennya suatu negara tentulah harus didukung oleh masyarakat yang memiliki mutu yang baik, fleksibel dalam artian dapat bersaing dengan masyarakat dari negara lain.

Perusahaan yang merupakan salah satu ujung tombak perekonomian suatu negara harus pula memperhatikan hal yang berkaitan dengan sumber daya manusianya. Sebab tenaga kerja dalam suatu perusahaan akan turut menentukan produktivitas demi tercapainya kesuksesan dan tujuan perusahaan. Sebagaimana pendapat Cascio (1987) yang menegaskan bahwa manusia adalah sumber daya yang sangat penting dalam bidang 
industri dan organisasi.

Terjadinya turn over merupakan suatu hal yang tidak dikehendaki oleh perusahaan dan memang merupakan masalah klasik yang sudah dihadapi para pengusaha sejak era revolusi industri (Hartati, 1982). Selanjutnya dijelaskan oleh McKinnon (Hartati, 1982) yang menyatakan bahwa kondisi lingkungan yang buruk, upah yang terlalu rendah, jam kerja melewati batas, serta tidak adanya jaminan sosial merupakan penyebab utama timbulnya turn over pada waktu itu. Sehingga dirasa perlu untuk segera melakukan usaha penanggulangan dari gejala kerja yang negatif tersebut.

Usaha yang dilakukan untuk menangani masalah turn over ini adalah dengan cara menumbuhkan dan meningkatkan keikatan kerja karyawan terhadap perusahaan. Hal ini telah dibuktikan dengan hasil penelitian yang menyebutkan bahwa turn over karyawan tidak hanya ditentukan oleh faktor gaji, dan kepuasan kerja, tetapi juga oleh ada tidaknya rasa keikatan kerja karyawan terhadap perusahaan (Steers dan Porter, 1983). Lebih jauh Hrebiniak \& Alluto menyatakan bahwa ditinjau dari sikap, keikatan kerja didefinisikan sebagai suatu fenomena struktural yang terjadi sebagai hasil dari transaksi antara individu dan organisasi dalam kepentingan persaingan ataupun investasi di masa yang akan datang (Steers dan Porter, 1983).

Beberapa kasus kecelakaan yang terjadi menunjukkan betapa pentingnya diciptakan suasana dan kondisi kerja yang aman terhindar dari kelalaian-kelalaian yang ada, menye- nangkan baik secara fisik maupun psikis, agar karyawan yang terlibat di dalamnya merasa kerasan dan produktivitasnya meningkat. Dengan demikian kesuksesan dan tujuan perusahaan dapat tercapai. Untuk menciptakan suasana yang demikian tentulah tidak lepas dari peran budaya keselamatan dan kesehatan kerja yang dikembangkan dalam perusahaan.

Faktor budaya bagi sebuah organisasi yang berorientasi profit akan dipengaruhi oleh penekanan dinamis antara empat faktor dasar dalam bisnis yaitu : produktifitas, kualitas, biaya, dan keselamatan (safety) (Du Pont, 1999). Faktor keselamatan tanpa pemenuhan produksi yang berkualitas akan menyebabkan industri menjadi tidak berarti apa-apa. Sementara itu ketika karyawan diberi beban kerja yang berlebih, akan sama artinya dengan penekanan terhadap karyawan. Budaya keselamatan dan kesehatan kerja perusahaan dapat ditumbuh kembangkan melalui perilaku karyawan yang terfokus pada keselamatan, produksi yang berkualitas, dan memastikan keselamatan bagi setiap karyawan. Usaha ini akan memerlukan kerjasama yang baik antara manajemen dan karyawan. Keinginan karyawan untuk memiliki kondisi kerja yang lebih baik dapat menjadi titik awal untuk mengembangkan budaya keselamatan dan kesehatan kerja.

Berdasarkan uraian tersebut maka dapat disimpulkan bahwa dengan budaya keselamatan dan kesehatan kerja yang kuat akan mendukung situasi kerja yang ada dalam perusahaan, sehingga karyawan akan bekerja secara optimal mengeluarkan segenap kemampuannya, terwujudnya produkti- 
vitas kerja yang tinggi, dan tingkat absensi, serta turn over karyawan di perusahaan menjadi rendah. Dengan pengertian lain, budaya keselamatan dan kesehatan kerja akan membentuk kohesivitas, kesetiaan dan mempengaruhi keikatan kerja karyawan terhadap perusahaan.

\section{TINJAUAN PUSTAKA}

Robbins (1986) menyatakan bahwa pengertian keikatan kerja sebagai suatu sikap yang menggambarkan orientasi individu terhadap organisasi, mengidentifikasikan diri, dan melibatkan dalam kegiatan organisasi tersebut. Riggio (1990) memberi pengertian yang lebih jelas mengenai keikatan, yaitu sebagai perasaan dan sikap-sikap yang dimiliki oleh karyawan berkaitan dengan organisasi kerja secara keseluruhan.

Guest (1992) menyatakan bahwa keikatan organisasi pada dewasa ini merupakan faktor yang penting dalam kehidupan suatu organisasi. Keikatan kerja merupakan alternatif baru dalam mengembangkan sistem pengelolaan sumberdaya manusia. Bilamana sistem pengelolaan sumber daya manusia selama ini menggunakan pendekatan penilaian prestasi kerja, pengawasan, maupun manajemen berdasarkan tujuan, maka keikatan kerja pada organisasi yang mampu ditumbuhkan akan memberikan keleluasaan pada organisasi untuk tidak perlu terlalu ketat menegakkan sistem pengendalian karyawan, karena karyawan dengan keikatan kerja yang tinggi akan bekerja sebaikbaiknya dan semaksimal mungkin.
Steers dan Porter (1983) lebih dulu mengemukakan pembagian keikatan kerja dalam dua kategori, yaitu: pengertian dalam kategori perilaku dan pengertian dalam kategori sikap. Secara perilaku seseorang yang mempunyai keikatan kerja terhadap perusahaan berarti tergantung pada aktivitas masa lalunya, atau jika seseorang telah mempunyai banyak tabungan di perusahaan, dalam arti banyak jasa yang telah diberikannya kepada organisasi, maka akan merasa sukar atau tidak mungkin untuk meninggalkannya. Mayer dan Allen (1984) sejalan dengan pendapat ini dan menjelaskan bahwa perilaku keikatan kerja adalah suatu usaha sosialisasi yang dilakukan seseorang karyawan dengn cara bertindak konsisten yang disebabkan adanya kekhawatiran hilangnya taruhan (side bet) bilamana tidak meneruskan aktivitas tersebut. Taruhan yang dimaksud dapat berbentuk waktu, pendapatan, status, ketrampilan maupun fasilitas lain dari perusahaan. Sementara Miner (1988) menunjukkan bahwa peningkatan keikatan kerja karyawan biasanya dikaitkan dengan berkurangnya absensi sampai meningkatnya kesediaan untuk kerja lembur.

Ditinjau dari pengertian suatu sikap, keikatan kerja dipandang sebagai suatu keadaan di mana seseorang mengidentifikasikan dirinya pada suatu organisasi beserta tujuan-tujuan yang akan dicapai, serta ingin tetap menjadi anggota di organisasi tesebut, atas kemauannya sendiri terlepas dari keuntungan-keuntungan ekonomik yang diperolehnya (Steers \& Porter, 1983; Mayer \& Allen, 1984). 
Banyak faktor yang mempengaruhi kuatnya keikatan kerja pada organisasi. Miner (1988) menyatakan bahwa persepsi karyawan terhadap menajemen yang dijalankan, budaya organisasi yang ada, dan sistem kerja memainkan peran penting terhadap keikatan kerja. Riggio (1990) menambahkan beberapa faktor yang mempengaruhi keikatan ini, yaitu tipe dan variasi pekerjaan, besarnya tanggung jawab yang dikaitkan dengan pelaksanaan pekerjaan, kualitas lingkungan sosial dalam pekerjaan, dan kompensasi yang diperoleh dari pekerjaan, serta kesempatan untuk promosi dan kenaikan jabatan yang memungkinkan.

Keikatan kerja pada organisasi membawa dampak positif bagi organisasi. Mellor (1990) menemukan hasil penelitian yang menunjukkan bahwa keikatan kerja berpengaruh pada penurunan keinginan untuk keluar dari keanggotaan perusahan, bersikap positif terhadap pekerjaan yang dilakukan, meningkatkan aktivitas kerja, dan tingkat partisipasi yang tinggi. Eissenberger dan Falso (1990) menemukan manfaat keikatan karyawan dapat ditandai dengan adanya peningkatan kecenderungan dalam mengutamakan keuntungan perusahaan melebihi keuntungan diri sendiri, membuat penilaian yang baik dalam evaluasi perusahaan, meningkatkan internalisasi norma dan nilai, partisipasi kerja tinggi, dan lebih rajin datang ke tempat kerja. Steers (1977) mengemukakan manfaat keikatan kerja karyawan bagi perusahan yang mendukung kelangsungan hidup perusahaan, yaitu: peningkatan kehadiran, kebetahan kerja, keterlibatan pada pekerjaan, peningkatan usaha, serta perasaan memiliki perusahaan.

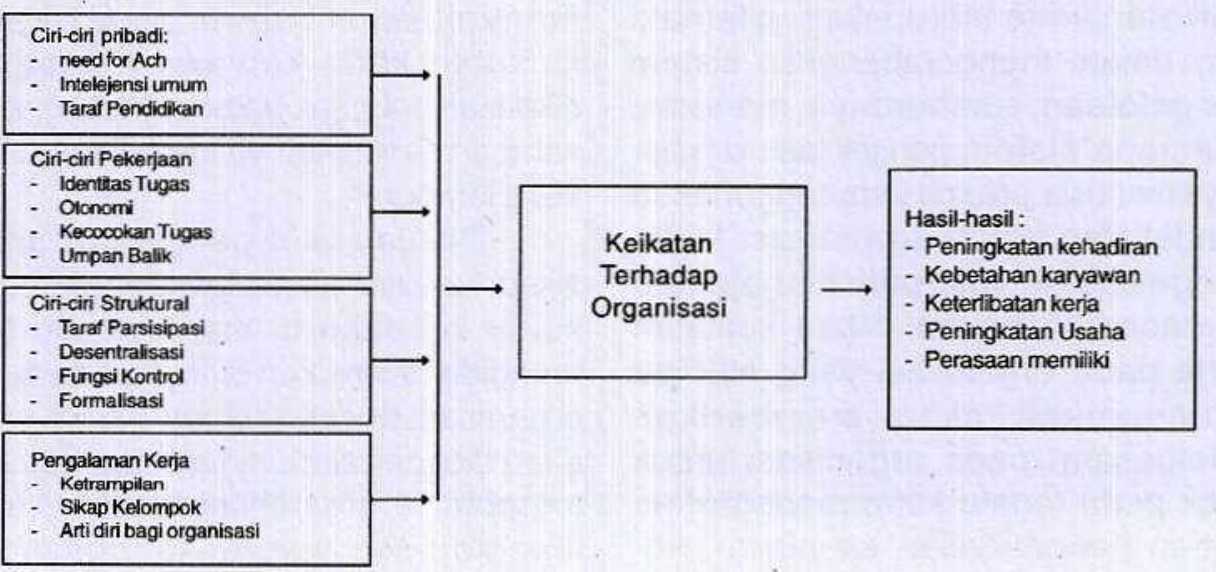

Gambar 1: Schema Model Manfaat Keikatan Kerja

(Sumber: Steers, 1988) 
Gambar 1 di atas menunjukkan bahwa karyawan yang benar benar menunjukkan keikatan kerja mempunyai identifikasi diri kepada tujuan dan nilainilai orgnisasi, menunjukkan tingkat partisipasi yang lebih tinggi dalam kegiatan organisasi. Kehadiran karyawan umumnya hanya terhalang jika menderita sakit, mengalami kecelakaan atau ada keperluan keluarga yang sangat penting, sehingga tingkat kemangkiran atau bolos yang disengaja pada karyawan tersebut akan lebih rendah dibandingkan dengan karyawan yang keikatan kerjanya rendah. Keikatan kerja yang kuat mendorong karyawan untuk terus memajukan perusahaan dengan bekerja sebaikbaiknya, karena karyawan merasa bahwa perusahaan adalah miliknya juga. Karyawan merasa telah menjadi bagian dari pesuhanaan sehingga segala usaha diwujudkan dalam perilaku yang nyata. Sebagaimana dikemukakan oleh Eissenberger dan Falso (1990) yang menyatakan bahwa karyawan yang terikat dengan perusahaan akan lebih berusaha untuk menyelesaikan tugasnya dan akan memperkecil keinginan untuk melihat dan menerima pekerjaan di perusahan lain.

Pada karyawan yang menunjukkan keikatan kerja tinggi memiliki keinginan yang lebih kuat untuk tetap bekerja pada perusahan yang sekarang agar terus dapat memberikan sumbangan bagi pencapaian tujuan. Koch dkk. (Steers, 1977) menunjukkan bahwa keikatan kerja merupakan alat peramal yang tepat bagi perpindahan karyawan dan menjadi lebih baik setelah karyawan mulai mengidentifikasi diri dengan organisasi dan tujuan-tujuannya. Peningkatan identifikasi dan kepercayaan karyawan terhadap tujuan organisasi memungkinkan beberapa karyawan yang kuat keikatan kerjanya akan sepenuhnya melibatkan diri pada pekerjaannya. Keikatan kerja yang kuat pada karyawan juga memungkinkan karyawan akan bersedia mengerahkan cukup banyak usaha demi kepentingan organisasi. Hal ini dapat mewujudkan hasil kerja yang sangat baik.

Peraturan Menteri Tenaga Kerja No. 05 tahun 1996 (Sahab, 1997), tentang sistem manajemen keselamatan dan kesehatan kerja menjelaskan bahwa yang dimaksud dengan kesehatan kerja adalah lapangan kesehatan yang ditujukan untuk memelihara dan mempertinggi derajat kesehatan tenaga kerja yang dilakukan dengan jalan mengatur pemberian pengobatan, perawatan tenaga kerja yang sakit, mengatur persediaan tempat, caracara dan syarat-syarat yang memenuhi norma-norma hygiene perusahaan dan kesehatan kerja untuk mencegah penyakit, baik sebagai akibat pelaksanan pekerjaan maupun penyakit umum, serta menetapkan syarat-syarat kesehatan bagi perumahan tenaga kerja.

Mulyono (1997) menjelaskan bahwa keselamatan dan kesehatan kerja merupakan bagian dari sistem manajemen secara keseluruhan yang meliputi struktur organisasi, perencanaan, tanggung jawab, pelaksanaan, prosedur, proses, dan sumber daya yang dibutuhkan bagi pengembangan, penerapan, pencapaian, pengkajian, dan pemeliharaan kebijakan kese- 
lamatan dan kesehatan kerja dalam rangka pengendalian resiko yang berkaitan dengan kegiatan kerja guna terciptanya tempat kerja yang aman, efisien, dan efektif.

Manullang (Darmawang, 1977) menyatakan bahwa keselamatan kerja adalah keselamatan yang bertalian dengan kecelakaan kerja, yaitu kecelakaan yang terjadi di tempat kerja. Sedangkan kesehatan kerja didefinisikan sebagai bagian dari ilmu kesehatan yang bertujuan agar pekerja memperoleh keadaan kesehatan yang sempurna, baik fisik, mental, sosial, sehingga pekerja dapat bekerja secara optimal.

Terdapat tiga tujuan pelaksanaan program keselamatan dan kesehatan kerja, yaitu melindungi tenaga kerja atas hak keselamatan dan kesehatan dalam melakukan pekerjaan untuk kesejahteraan hidup dan meningkatkan produksi serta produktivitas nasional; menjamin keselamatan setiap orang yang berada di tempat kerja; sumber produksi dipelihara dan dipergunakan secara aman dan efisien (Suma'mur, 1995). Lebih lanjut dinyatakan bahwa keselamatan kerja mempunyai hakekat sebagai alat untuk mencapai derajat kesehatan tenaga kerja yang setinggitingginya, baik buruh, petani, nelayan, pegawai negeri, atau pekerja-pekerja bebas. Hal ini senada dengan pendapat Flippo (1984) yang menyatakan bahwa keselamatan dan kesehatan kerja bertujuan membantu mengurangi terjadinya kecelakaan dan penyakit yang disebabkan oleh industri, serta membantu memelihara, dan melestarikan kondidi jasmani para karyawan.

Mulyono (1997) menyebutkan adanya sebab-sebab terjadinya kece- lakaan di tempat kerja yang dapat digolongkan menjadi dua hal yang utama, yaitu: sebab-sebab teknis, dan sebab-sebab perilaku manusia (human error). Disebutkan sebab-sebab teknis antara lain menyangkut prosedur kerja yang tidak aman, buruknya lingkungan kerja, penerangan yang kurang memenuhi syarat, mesin-mesin dan peralatan kerja yang kurang terpelihara, suara bising yang berlebihan, kebersihan tempat kerja tidak terjaga, dan ventilasi yang buruk. Sedang sebab perilaku manusia (human error) dapat disebabkan oleh sikap ceroboh, kurang hatihati yang disebabkan oleh deficiencies individual seperti tidak mampu menjalankan tugas dengan baik mengantuk, pecandu alkohol, atau obat bius, dan orang memamg mempunyai bakat untuk mengalami kecelakaan berulang (accident prone indiiduals), serta adanya pengawasan yang rendah kualitasnya. Silalahi \& Silalahi (1995) menyebutkan tiga sebab mengapa timbul kecelakaan kerja, yaitu: karyawan tidak mengetahui tata cara yang aman dari perbuatanperbuatan berbahaya; karyawan tidak mampu memenuhi persyaratan kerja sehingga terjadi tindakan di bawah standar yang ditentukan; karyawan mengetahui seluruh peraturan dan persyaratan kerja, tetapi tidak bersedia memenuhi atau mematuhinya. Selain hal tersebut di atas, terjadinya kecelakaan kerja menurut Flippo (1994) dapat mengakibatkan hilangnya hari-hari kerja. Hal ini didukung oleh Mulyono (1997) yang menyatakan bahwa kecelakaaan kerja dapat mengakibatkan jatuhnya korban manusia, dan timbulnya kerugian harta benda. Ranupandojo \& Husnan (1993) menyebutkan bahwa kecela- 
kaan kerja dan kesehatan karyawan yang buruk akan mengakibatkan kecenderungan adanya tingkat absensi yang tinggi dan rendahnya tingkat produktivitas kerja.

Budaya keselamatan dan kesehatan kerja adalah pembentukan perilaku keselamatan kerja yang terus menerus diulang (Silalahi \& Silalahi, 1995). Hal ini didukung oleh Matthis (1999) yang menyatakan bahwa budaya keselamatan dan kesehatan kerja tergantung observasi dan partisipasi pekerja terhadap program keselamatan. Dengan demikian berarti pekerja dituntut untuk selalu melakukan tindakan yang aman dalam proses berproduksi.

Miner (1988) melihat adanya keterkaitan antara keikatan kerja karyawan dengan absensi dan kualitas maupun kuantitas outputperusahaan. Keikatan kerja yang tinggi mempunyai hubungan dengan rendahnya absensi dan tingginya produktivitas. Dalam hal ini semakin baik budaya keselamatan dan kesehatn kerja, maka semakin baik pula kikatan kerja karyawan pada perusahaan. Sebagaimana yang dikemukakan oleh Poerter dkk. (O'Reilly \& Chatman, 1986) bahwa keikatan kerja terhadap organsiasi adalah kekuatan relatif identifikasi indiviidu dan keterlibatannya di dalam organisasi tersebut.

Tahapan penting dalam budaya keselamatan dan kesehatan kerja adalah mengarahkan sikap karyawan terhadap perusahaan, kekayaan perusahan, dan terhadap karyawan lain. Sikap ini dapat dilihat pada apa yang dilakukan oleh para karyawan terhadap perlakuan dan, apa yang didiskusikan dengan karyawan lain. Oleh karena itu dalam pengembangan sistem budaya keselamatan dan kesehatan kerja akan selalu melibatkan persepsi karyawan, karena persepsi akan mempengaruhi perilaku dan perilaku yang berulang-ulang akan menjadi suatu kebiasaan. Kebiasaan ini akan terkondisikan menjadi perilaku yang didasari sikap karyawan terhadap perusahaan. Keikatan kerja karyawan dapat diamati dari respon emosionalnya terhadap perusahaan secara keseluruhan, termasuk pelaksanaan program budaya keselamatan dan kesehatan kerja.

\section{HIPOTESIS}

Ada hubungan positif antara budaya keselamatan dan kesehatan kerja dengan keikatan kerja karyawan.

\section{METODE PENELITIAN}

Subyek dalam penelitian ini adalah karyawan sebuah perusa-haan industri tekstil di wilayah Surakarta, dengan tingkat jabatan staf. Subyek yang digunakan dalam penelitian ini sudah ditentukan ciri-cirinya, yaitu karyawan tetap dengan jenis kelamin laki-laki dan perempuan, telah bekerja di perusahaan tersebut sekurangkurangnya 12 (duabelas) bulan, dan berpendidikan serendah-rendahnya SLTA atau sederajat.

Alasan pemilihan subyek karyawan tetap karena subyek sudah dapat melihat kesesuaian antara kebutuhan-kebutuhannya dengan kebutuhan-kebutuhan perusahaan sehingga memiliki kesamaan dalam hal meramalkan masa depannya di perusahaan tersebut. Masa kerja minimal 12 (dua belas) bulan berarti karyawan telah 
memiliki waktu yang cukup untuk memahami budaya keselamatan dan kesehatan kerja perusahaannya. Pemilihan tingkat pendidikan SLTA dan sederajat dengan harapan karyawan memiliki aspirasi yang sama dalam memberikan penilaian. Sampel diambil dengan menggunakan teknik quota sampling.

Kepada sebanyak 100 orang karyawan dibagikan masing-masing satu set skala, yang terdiri atas skala Budaya Keselamatan dan Kesehatan Kerja, dan Skala Keikatan Kerja Karyawan, subyek terdiri atas karyawn di bagian weaving sebanyak 50 orang, dan di bagian finishing 50 orang. Skala yang dikembalikan untuk dianalisis sesuai tujuan penelitian sebanyak 94 set skala.

Variabel tergantung adalah keikatan kerja dan variabel bebas adalah budaya keselamatan dan kesehatan kerja. Pengukuran kedua variabel dilakukan dengan Skala Budaya Keselamatan dan Kesehatan Kerja yang dikembangkan oleh Pusat Studi Lingkungan Hidup Universitas Gadjah Mada (PSLH UGM, 2001). Hasil uji coba menunjukkan dari sebanyak 56 butir pernyataan dalam skala, ternyata 19 butir yang gugur, sehingga hanya terdapat 37 butir yang valid. Koefisien korelasi bergerak dari $\mathrm{rbt}=0,283$ sampai dengan $\mathrm{rbt}=0,591$; $p<0,05$. Reliabilitas skala ini (alpha) $=0,8739$. Alat ukur yang lain ialah Skala Keikatan Kerja Karyawan yang dikembangkan oleh Sri Laksmi Purnama Dewi. Skala yang mencakup 50 butir pernyataan ini setelah diuji cobakan ternyata terdapat 20 butir yang gugur, sehingga tinggal 30 butir valid. Koefisien validitas bergerak dari rbt $=0,283$ sampai dengan $\mathrm{rbt}=$ $0,5803, p<0,05$. Sedangkan, indeks reiabilitas yang diperoleh (alpha) = 0,732 .

Metode analisis data yang akan digunakan untuk pengujian hipotesis dalam penelitian ini adalah teknik korelasi Product Moment dari Karl Pearson. Metode ini digunakan karena penelitian ini ingin mengungkap hubungan antara variabel Budaya Keselamatan dan Kesehatan Kerja dengan Keikatan Kerja Karyawan. Sebelum dilakukan analisis, terlebih dahulu dilakukan uji asumsi.

\section{HASIL PENELITIAN DAN PEMBAHASAN}

Uji normalitas digunakan untuk kepentingan generalisasi hasil penelitian, agar hasil penelitian dapat digeneralisasikan pada populasi baik di perusahaan tempat penelitian, maupun di luar populasi yang mempunyai karakteristik yang hampir sama. Berdasarkan uji normalitas sebaran yang dilakukan dengan Test One Sample Kolmogorov - Smirnov, diperoleh hasil kedua variabel terdistribusi normal. Variabel bebas yaitu budaya $\mathrm{K} 3$ memiliki $\mathrm{p}=0,402$ $(>0,05)$ dan variabel tergantung, yaitu keikatan kerja memiliki $\mathrm{p}=0,160$ $(>0,05)$.

Huburigan antara dua variabel dikatakan linear jika $p<0,05$. Uji linearitas variabel bebas terhadap variabel tergantung menghasilkan $F=$ 183.131 dengan $p=0.00$. Dengan demikian hubungan antara dua variabel tersebut linear. 
Hasil analisis korelasi menunjukkan adanya hubungan positif yang signifikan antara budaya $\mathrm{K} 3$ dengan keikatan kerja karyawaan dengan ( $r$ ) $=0.771$ dan $p=0,001$. Dengan demikian hipotesis yang menyatakan ada hubungan positif antara keikatan kerja dengan budaya kesehatan dan keselamatan kerja pada karyawan dapat diterima. Dari data tersebut selanjutnya dapat diketahui koefisien determinasi $\left(r^{2}=0,595\right)$ yang berarti budaya kesehatan dan keselamatan kerja menyumbang sebesar $59,5 \%$ terhadap keikatan kerja. Sebesar $40,5 \%$ lainnya adalah sumbangan variabel lain.

Analisis data dengan korelasi product moment dari Pearson antara variabel keikatan kerja dengan variabel budaya K3 menunjukkan koefisien korelasi $(r)=0,771, p<0,01$ dan koefisien determinan $\left(r^{2}\right)=0,595$. Hal ini menunjukkan bahwa hipotesis penelitian yang menyatakan bahwa ada hubungan positif antara keikatan kerja dengan budaya keselamatan dan kesehatan kerja dapat diterima. Semakin tinggi budaya keselamatan dan kesehatan kerja yang diterapkan perusahaan akan diikuti dengan semakin tingginya keikatan kerja karyawan.

Data penelitian menunjukkan rerata empirik yang lebih besar dari rerata hipotetik pada kedua variabel. Variabel budaya $\mathrm{K} 3$ memiliki rerata empirik Mek3 $=110,32$ dan rerata hipotetik Mhk3 $=55,5$. Variabel keikatan kerja memiliki rerata empirik sebesar Mekk $=93,52$ dan rerata hipotetik Mhkk $=45$. Hal ini menunjukkan bahwa karyawan yang menjadi subjek penelitian ratarata memiliki budaya kesehatan dan keselamatan kerja dan keikatan kerja yang tinggi.

Setelah dilakukan penggolongan berdasarkan kategori tinggi, sedang, dan rendah ditemukan bahwa karyawan di industri tekstil ini umumnya memliki budaya keselamatan dan kesehatan kerja kategori tinggi sebanyak 92 orang, kategori sedang sebanyak 2 orang. Karyawan memiliki keikatan kerja, dengan kategori sedang sebanyak 5 orang dan kategori tinggi sebanyak 89 orang. Sedangkan kategori rendah pada kedua variabel tidak dijumpai.

Mayer dan Allen (1984) menjelaskan bahwa perilaku keikatan kerja adalah sebagai suatu usaha sosialisasi yang dilakukan sesorang dengan cara bertindak konsisten disebabkan adanya kekhawatiran hilangnya taruhan (site bet) apabila ia tidak meneruskan aktivitas tersebut. Taruhan di sini dapat berupa waktu, uang, status, keterampilan maupun fasilitas dari perusahaan. Kondisi ekonomi di Indonesia sekarang ini berada pada taraf ekonomi yang memprihatinkan, sehingga bagi karyawan yang merasakan imbas krisis ekonomi tidak mempunyai pilihan lain selain harus tetap bekerja. Dengan bekerja, taruhan ekonomi seperti uang, status yang didapatkannya dari perusahaan tidak akan hilang. Kehilangan yang dimaksud disini adalah hilangnya pekerjaan yang secara harafiah mendatangkan keuntungan ekonomi.

Pentingnya ekonomi bagi karyawan pada hakikatnya adalah 
pemenuhan rasa aman kerja yang dirasakan karyawan. Hal ini akan dapat dicapai bila produksi perusahaan berjalan konsisten. Untuk menimbulkan konsistensi ini salah satunya dapat ditimbulkan dengan menumbuhkan budaya keselamatan dan kesehatan kerja. Ketika seseorang dapat merasakan kondisi kerja yang nyaman maka kondisi ini dapat mempengaruhi afeksi gairah, perilaku dan semangat dalam bekerja, yang pada akhirnya akan berhubungan dengan output pekerja (Myers, 1954).

Industri tekstil adalah industri yang sifatnya menuntut pemenuhan produksi yang kontinyu. Pencapaian produksi yang kontinyu akan dapat dicapai jika sistem operasi perusahaan dapat dijalankan dengan baik oleh manajemen. Pengelolaan indutri tekstil menuntut kehadiran dari para karyawan secara terus-menerus.

Steers \& Porter (1983) melihat adanya keterkaitan antara keikatan kerja karyawan dengan absensi, kualitas maupun kuantitas output perusahaan. Keikatan kerja yang tinggi mempunyai hubungan positif dengan rendahnya absensi dan tingginya produktifitas. Pendapat Steers \& Porter (1983) menjelaskan hasil penelitian ini yang menunjukkan tingginya keikatan kerja karyawan. Artinya dengan kehadiran karyawan secara terus-menerus akan mampu menumbuhkan perasaan memiliki terhadap pekerjaan yang ditekuninya. Hal ini ditunjang dengan pengadaan sumber tenaga kerja untuk bagian non-staf yang diambil dari penduduk sekitar perusahaan. Hubungan tersebut lebih kuat bila dibandingkan dengan kepuasan kerja, dengan kata lain akan lebih mudah untuk melihat kecenderungan terjadinya turn over bila dikaitkan dengan ada tidaknya rasa keikatan kerja karyawan terhadap perusahaan tempat karyawan bekerja daripada bila mengkaitkannya dengan kepuasan kerja karyawan tersebut. Artinya semakin tinggi keikatan kerja terhadap perusahaan akan memperkecil kemungkinan terjadinya turn over. $\mathrm{Hal}$ ini didukung juga oleh pendapat Davis dan Newstrom (1989) yang menyatakan bahwa karyawan yang memiliki keikatan kerja terhadap perusahaan biasanya mempunyai tingkat absensi yang rendah, kemauan untuk mentaati aturan perusahaan dan tingkat turn overyang rendah.

Zohar (1980) menemukan perusahaan yang mempunyai iklim keselamatan yang baik akan meningkatkan lingkungan kerja yang aman dibandingkan dengan perusahaan tanpa iklim keselamatan, sehingga perusahaan yang menetapkan keselamatan kerja sebagai suatu prioritas dapat meningkatkan perilaku keselamatan dan mengurangi kecelakaan.

Upaya kesehatan dan keselamatan kerja di perusahaan ini telah dilakukan melalui penyediaan dokter perusahaan atau petugas kesehatan, melakukan pemeliharaan dan pengecekan peralatan kerja secara teratur, diskusi masalah kesehatan dan keselamatan kerja antar karyawan, penyediaan jaminan asuransi kecelakaan kerja.

Pentingnya kondisi kerja yang aman, nyaman dapat menjadikan karyawan merasa memiliki keikatan kerja yang semakin baik pada perusahaan. Karena setiap individu cenderung untuk 
mempersepsikan segala sesuatu dalam lingkungan dirinya. Dalam hal ini tentunya karyawan sebagai individu akan mempersepsikan hal-hal yang berkaitan dengan pekerjaannya. Jika karyawan dapat merasakan keberhasilan atau ketidakberhasilan budaya keselamatan dan kesehatan kerja maka akan mempengaruhi sikapnya terhadap pekerjaan, yakni akan menimbulkan reaksi positif atau negatif dalam sikap karyawan pada perusahaan. Sikap yang positif akan dapat meningkatkan keikatan karyawan pada perusahaan sedangkan sikap negatif akan menimbulkan keresahan karyawan pada pekerjaannya.

Penerimaan terhadap hipotesis penelitian ini dapat memberikan gambaran yang berarti, bahwa budaya kesehatan dan keselamatan kerja mempunyai hubungan yang positif dengan keikatan kerja karyawan pada perusahaan. Hal ini terjadi karena dengan adanya budaya keselamatan dan kesehatan kerja berarti para karyawan memiliki sikap yang positif kepada perusahaan tempat bekerja. Dengan sikap positif ini menjadikan karyawan untuk lebih giat bekerja, karena antara karyawan dan perusahaan dapat saling menerima dan saling mempercayai tujuan masing-masing. Antara karyawan dan perusahaan saling menghormati satu sama lainnya. Dengan demikian terjadi saling ketergantungan dan kerjasama. Karyawan merasa tidak berarti jika tidak berbuat sesuatu demi keuntungan perusahaan. Oleh karena itu perusahaan juga berusaha memberikan bentuk perlindungan melalui penerapan keselamatan dan kesehatan kerja bagi para karyawan, demikian pula dengan para karyawan itu sendiri berusaha lebih giat bekerja demi mencapai tujuan perusahaan. Kenyataan seperti ini juga berlaku bagi para karyawan bagian produksi perusahaan tekstil yang menjadi obyek penelitian.

Dalam hubungan timbal balik yang demikian ini masing-masing pihak menemukan stabilitas, perusahaan menemukan mitra kerja yang dapat dipercaya untuk membantu memecahkan masalah yang dihadapi perusahaan. Sedang karyawan menemukan tempat berakar, merasa dihargai, tidak diabaikan, dianggap sebagai warga dan dapat bekerja dengan senang hati sehingga karyawan rela bekerja dengan lebih keras dan lebih baik daripada semula.

Keikatan kerja karyawan itu sendiri mempunyai arti yang lebih luas bukan hanya terjadi hubungan timbal balik dan ketergantungan antara karyawan dan perusahaan tempat bekerja. Hal ini juga akan menimbulkan loyalitas di antara para karyawan sendiri sebagai suatu kelompok (Steers \& Porter, 1983). Pada dasarnya manusia itu membentuk kedekatan emosional dengan orang yang berinteraksi dengannya serta merasa lebih aman dan nyaman dengan kehadiran orang lain. Oleh karena itu diantara para karyawan berusaha menjalin hubungan yang baik satu dengan lainnya baik sesama teman sekerja ataupun antara atasan dan bawahan. Individu yang dapat menerima dan menerapkan budaya kesehatan dan keselamatan kerja akan bertahan di perusahaan tersebut karena mempunyai kesamaan nilai-nilai dan tujuan organisasi mengingat budaya kesehatan dan 
keselämatan kerja itu sendiri merupakan internalisasi pengelolaan dan penerapan sistem manajemen kesehatan keselamatan dan kesehatan kerja pada semua level karyawan baik pada level manajemen, organisasi, fasilitas, prosedur-prosedur dan pemenuhan atau pematuhan terhadap peraturan keselamatan dan sarana peralatan dengan menekankan pada partisispasi dan keterlibatan karyawan terhadap keselamatan kerja. Dengan budaya keselamatan kesehatan kerja yang selalu ditingkatkan akan menjadikan hubungan yang dekat dan baik serta akan lebih memperkokoh keikatan kerja yang terjadi, sehingga akan mempermudah dalam mengambil langkah terbaik dan saling menguntungkan. Dengan keikatan kerja karyawan yang kuat segala permasalahan akan menjadi lebih mudah teratasi karena antara karyawan dan perusahaan dapat saling membantu.

\section{KESIMPULAN DAN SARAN}

Hasil penelitian menyatakan bahwa ada hubungan positif yang signifikan antara budaya keselamatan dan kesehatan kerja dengan keikatan kerja, berarti semakin baik budaya keselamatan dan kesehatan kerja perusahaan akan diikuti dengan semakin kuatnya keikatan kerja karyawan. Begitu juga sebaliknya semakin jelek budaya keselamatan dan kesehatan kerja akan diikuti dengan semakin lemahnya keikatan kerja karyawan. Hasil tambahan yang diperoleh dari penelitian ini adalah sumbangan efektif dari variabel budaya keselamatan dan kesehatan kerja terhadap keikatan kerja pada organisasi sebesar $59,5 \%$. Hal ini menun- jukkan bahwa budaya keselamatan dan kesehatan kerja menyumbang sebesar $59,5 \%$ terhadap keikatan kerja karyawan. Sisanya sebesar $41,5 \%$ dipengaruhi oleh variabel lainnya misalnya intensi turn over, absensi, masalah keluarga, tipe kepribadian.

Saran yang dikemukakan sehubungan dengan hasil penelitian ini ialah:

a. Perusahaan perlu untuk memperjelas arah dan pengembangan dari budaya kesehatan dan keselamatan kerja yang diinginkannya sesuai dengan karakteristik industri tekstil. Sebagai contoh adalah menyediakan sistem manajemen safety terpadu dimana antara karyawan dan manajemen sama-sama terlibat secara jujur dalam mengobservasi lingkungan kerjanya masingmasing.

b. Bagi departemen personalia perlu mengadakan divisi safety secara khusus, sebagai elemen penting safety regulator. Tugas dari divisi ini adalah mensosialisaikan program safety yang sudah direncanakan oleh perusahaan. Hal ini dapat dilakukan dengan memberi pelatihan supervisi program keselamatan dan kesehatan kerja pada para supervisor, menyediakan dan memberikan kepelatihan dalam hal keselamatan dan kesehatan kerja seperti APAR (Alat Pemadam Api Ringan), breathing aparatus, fire fighting dan lain-lain. Disamping itu penyediaan sarana untuk melaporkan kondisi kerja yang tidak aman yang sifatnya fleksibel, mudah dimengerti dan mudah didapat akan sangat membantu menumbuhkan 
rasa memiliki terhadap kondisi kerja para karyawan. Penyediaan sarana laporan kondisi kerja dalam bentuk check list akan sangat membantu menumbuhkembangkan budaya kesehatan dan keselamatan kerja di tempat kerja karyawan.

c. Penelitian keikatan kerja karyawan terhadap organisasi dapat dilakukan dengan menggunakan beberapa pendekatan seperti kualitas pelimpahan tanggung jawab kerja, perencanaan desain kerja, tipe dan variasi kerja, kualitas lingkungan sosial dalam pekerjaan, kompensasi, dan kesempatan untuk promosi dan kenaikan jabatan dalam perusahaan tersebut.

d. Penelitian budaya keselamatan dan kesehatan kerja dapat menggunakan variabel lain yang sesuai seperti, tingkat keterlibatan atasan dalam program keselamatan dan kesehatan kerja, jalur komunikasi, serta pelatihan keselamatan dan kesehatan kerja.

\section{DAFTAR PUSTAKA}

Cascio, W.F. 1987. Applied Psychology in Personnel Management. New Jersey: Prentice - Hall Inc.

Davis, K\& Newstrom, J.W. 1989. Human Behaviorat Work: Organizational Behavior. Singapore ; McGrawHill Book Company. Inc.

Darmawang, 1997. Persepsi terhadap Pelaksanaan K-3 Kaitannya dengan Kinerja Karyawan. Thesis. (Tidak diterbitkan)
Yogyakarta: Pasca Sarjana UGM.

Eissenberger, R. dan Falso, P. 1990. Rerceived Organizational Support and Employee Dilligence, Commitment, and Innovation. Joumal of Applied Psychology, Vol. 75, No. 1.

Flippo, E.B. 1984. PersonnelManagement. Singapore: McGraw-Hill Book Company.

Guest, D.E. 1992. Employee Commitment and Control, dalam Hartley, J.F. \& Stepherson, G.M. Employement - Relation, The Psychology of Influence and Control at Work. Oxford: Blackwell Publishers.

Hartati, T. 1982. Hubungan Antara Persepsi Terhadap Peluang Pengembangan Karir dengan Instansi Turn Over pada Karyawan PT Rajawali Nusantara Indonesia di Jakarta. Skripsi (tidak diterbitkan) Yogyakarta : Fakultas Psikologi UGM.

Mayer, J.P \& Allen, N.J 1984, Testing the "Site - Bet" Theory " of Organizational Comitment : Some Methode Logical Considerations Journal of Applied Psychology. Vol. 69 no. 3, 372 378.

Matthis, T. 1999. Motivation Employees to Accept: A Behavioral Safety Process: It's not about Pointing 
Blame. www.Vehavioral Safety.Com.

Miner, J.B. 1988. Organizational Behavior. USA: Random House Business Division.

Mellor, S. 1990. The Relation Between Membership Decline and Union Commitment: A Field Study of Local in Crisis. Joumal of Applied Psychology, Vol. 75, №. 3.

Muljono, L. E. 1997. Peraturan Sistem Manajemen Keselamatan dan Kesehatan Kerja. Jakarta: Arvarindo.

Myers, S.C., 1954. Industrial Psychology. Toronto: Oxford University Press.

O'Reilly, C.A. \& Chatman, J.A. 1986. Organizational Commitment and Psychological Attachment: The Effect of Compliance, Identificational, and Internalization on Prosocial Behavior. Journal of Applied Psychology. Vol. 71, 492-499.

PSLH UGM. 2001.Kajian Budaya dan Aspek Keselamatan dan Kesehatan Kerja dan Lingkungan di Pertamina. Lapaoran Penelitian. Yogyakarta: Pusaî Studi Lingkungan Hidup Universitas Gadjah Mada.

Ranupandojo, H. dan Husnan, S. 1993. Manajemen Personalia. Yogyakarta: BPFE.
Riggio, R.E. 1990. Introduction to Industrial/Organizaational Psychology. London: Scott Foreman \& Company.

Robbins, S.P. 1986. Orgnizational Behavior: Concepts, Controversies and Applications. Engelwood Cliffs: Prentice Hall Inc.

Steers, R.M \& Porter, L.M, 1983 Motivation and Work Behavior. New York : Mc Graw - Hill Book Company. Inc

Steers, R.M. 1977. Efektifitas Organisasi. (terjemahan). Jakarta: Erlangga.

Sahab, S. 1997. Teknik Manajemen Keselamatan dan Kesehatan Kerja. Jakarta: Pustaka Binaman Pressindo.

Silalahi, B.N. dan Silalahi, R.B. 1995. Manajemen Keselamatan dan Kesehatan Kerja. Jakarta: PT Pustaka Binaman Pressindo.

Suma'mur, P.K. 1995. Keselamatan Kerja \& Pencegahan Kecelakaan. Cet. 8. Jakarta: PT Gunung Agung.

Zohar, D., 1980. Safety Climate in Industry: Theoritical and Applied Implications. Journal Applied Psychology, Vol 65, No 1, page $96-102$ 